\title{
PENGUATAN KELEMBAGAAN LOKAL \\ (Sinergitas Balai Taman Nasional dengan Masyarakat Kelurahan Habaring Hurung dalam Mengelola Kawasan Taman Nasional Sebangau)
}

\author{
Oleh: R. RENALDO MANALU \& BHAYU RHAMA
}

\begin{abstract}
ABSTRAK
Penelitian ini berbicara tentang Penguatan kelembagaan Lokal dan Sinergitas Balai Taman Nasional Sebangau dengan Masyarakat Kelurahan Habaring Hurung dalam Mengelola Taman Nasional Kawasan Sebangau, melihat bahwa Taman Nasional Sebangau merupakan kawasan pelestarian alam Kawasan Taman Nasional Sebangau yang mempunyai sifat ekosistem yang unik dilihat dari struktur jenis tanah, topografi, hidrologi, flora dan fauna.

Tujuan penelitian ini adalah untuk mendeskripsikan dan menganalisis Penguatan kelembagaan Lokal dan Sinergitas Balai Taman Nasional Sebangau dengan Masyarakat Kelurahan Habaring Hurung dalam Mengelola Taman Nasional Kawasan Sebangau. Untuk menganalisisnya, peneliti menggunakan teori Dimensi Pembangunan Kapasitas Merille S. Grindle yang terdiri dari tiga dimensi yang menjadi ukuran pembangunan kapasitas yaitu Pengembangan Sumber Daya Manusia (SDM), Penguatan Organisasi, dan Reformasi Kelembagaan serta ditambahkan Konsep Dana Anggaran untuk menguatkan teori pembangunan kapasitas.

Penelitian ini termasuk dalam jenis penelitian deskriptif dengan menggunakan metode kualitatif. Pengumpulan data dilakukan dengan observasi, wawancara dan dokumentasi. Selain itu, teknik analisis data berupa pengumpulan data, reduksi data, penyajian data dan penarikan kesimpulan.

Hasil penelitian menunjukan bahwa pengembangan sumber daya Balai Taman Nasional Sebangau cukup bagus, penguatan organisasi berjalan dengan baik dan reformasi kelembagaan dalam visi dan misi telah dilaksanakan dengan baik. Akan tetapi kurang bersinerginya Balai Taman Nasional Sebangau dengan Masyarakat Kelurahan Habaring Hurung dapat dilihat dari kurangnya komunikasi yang dilaksanakan. Jadi diharapkan kedepannya Balai Taman Nasional Sebangau rutin melakukan kunjungan-kunjugan ke wilayah masyarakat agar masyarakat mengetahui pentingnya Taman Nasional Sebangau bagi kehidupan manusia.
\end{abstract}

\section{Kata Kunci: Sinergitas, Taman Nasional Sebangau, Kelurahan Habaring Hurung}

\section{PENDAHULUAN}

Dalam Undang-Undang No. 5 Tahun 1990 tentang Konservasi Sumber Daya Alam dan Ekosistemnya, Taman Nasional adalah sebagai Kawasan Pelestarian Alam (KPA) yang mempunyai ekosistem asli, dikelola dengan sistem zonasi yang dimanfaatkan untuk tujuan penelitian, ilmu pengetahuan, pendidikan, menunjang budidaya, pariwisata, dan rekreasi. Di Indonesia meskipun tidak semua kawasan konservasi yang mendapatkan status atau label Taman Nasional namun seluruh Taman Nasional kita memenuhi syarat untuk dikategorikan area yang dilindungi yaitu suatu kawasan yang ditetapkan khususnya bagi perlindungan dan pemeliharaan keanekaragaman hayati, sumber daya alam, dan budaya yang dikelola.

Berdasarkan informasi dari web Taman Nasional Sebangau bahwa Taman Nasional kawasan Sebangau ditunjuk pada tanggal 19 Oktober 2004 dengan luas +568.700 ha dan dibentuk pada tanggal 2 Juni 2006. Selanjutnya diperbaharui kembali pada tanggal 1 Februari 2007 tentang Organisasi dan Tata Kerja Unit Pelaksana Taman Nasional. Balai Taman Nasional Sebangau adalah institusi yang bertanggung jawab terhadap pengelolaan Taman 
Nasional Sebangau yang dinaungi oleh Kementrian Kehutanan. Balai Taman Nasional Sebangau berperan dalam hal melindungi dan melestarikan ekosistem hutan rawa gambut sebagai sistem penyangga kehidupan, menjamin kelestarian sumber daya alam hayati terutama flora dan fauna dilindung agar tidak punahnya binatang yang dianggap sudah langka dan memberikan manfaat berkelanjutan bagi masyarakat, terutama masyarakat lokal.

Saat ini, sebagian penduduk di sekitar Taman Nasional Sebangau mulai keluar desa/daerah untuk menjadi buruh perkebunan di perusahaan sawit seperti di Kecamatan Kamipang dan Kecamatan Mendawai yang berhijrah ke Kabupaten Katingan, Kotawaringin Barat dan Kotawaringin Timur. Salah satu alasan berpindahnya penduduk yang tinggal disekitar kawasan Taman Nasional Sebangau yaitu karena kebebasan masyarakat dalam penggunaan hutan dibatasi oleh terbitnya Undang-Undang Nomor 41 Tahun 1999 Tentang Kehutanan pada pasal 50 ayat 1 dan 3 yang menjelaskan bahwa setiap orang dilarang merusak prasarana dan sarana perlindungan hutan dan mengerjakan atau menggunakan dan atau menduduki kawasan hutan secara tidak sah serta merambah kawasan hutan. Apabila masyarakat melanggar peraturan tersebut maka akan dikenakan sanksi yaitu ancaman pidana penjara paling lama 10 (sepuluh) tahun dan denda paling banyak Rp 5.000.000.000,00 (lima milyar rupiah).

Masyarakat tidak hanya ditekankan untuk tidak merambah dan menggunakan kawasan Taman Nasional tetapi masyarakat juga memiliki peran untuk menjaga kelestarian ekosistem Taman Nasional. Sesuai dengan Peraturan Pemerintah No. 108 Tahun 2015 pasal 1 nomor 20 dijelaskan bahwa peran serta masyarakat adalah peran aktif masyarakat untuk ikut serta mewujudkan tujuan pengelolaan Kawasan Suaka Alam dan Kawasan Pelestarian Alam. Oleh karena itu, pemerintah dan masyarakat harus berkerja sama dalam hal menjaga kelestarian ekosistem kawasan Taman Nasional. Dalam hal ini, diperlukan adanya penguatan kelembagaan pemerintah lokal dalam mensinergikan Balai Taman Nasional dengan Masyarakat dalam mengelola Taman Nasional Kawasan Sebangau. Tujuannya tidak lain adalah agar Taman Nasional tetap mempunyai Ekosistem asli, serta dikelola dan dimanfaatkan untuk tujuan penelitian, ilmu pengetahuan, pendidikan, menunjang budidaya, pariwisata, dan rekreasi. Maka dari itu, disini peneliti tertarik untuk meneliti Penguatan Kelembagaan Lokal (Sinergitas Balai Taman Nasional dengan Masyarakat dalam Mengelola Taman Nasional Kawasan Sebangau).

Adapun rumusan masalah dalam penelitian ini adalah :

1. Bagaimana Penguatan Kelembagaan Lokal Melalui Balai Taman Nasional dalam Mengelola Taman Nasional Kawasan Sebangau?

2. Bagaimana Sinergitas Balai Taman Nasional dengan Masyarakat Kelurahan Habaring Hurung dalam Mengelola Taman Nasional Kawasan Sebangau?

\section{LANDASAN TEORI}

\section{Pembangunan Berkelanjutan}

Istilah pembangunan menurut Todaro dalam Damayanti (2010) pada hakikatnya merupakan cerminan proses terjadinya perubahan sosial suatu masyarakat, tanpa mengabaikan keragamaan kebutuhan dasar dan keinginaan individual maupun kelompok sosial atau institusi yang ada di dalamnya untuk mencapai kondisi kehidupan yang lebih baik. Sedangkan istilah pembangunan berkelanjutan (sustainable development) menurut Brundtland Report dari PBB (1987) adalah proses pembangunan yang mencakup tidak hanya wilayah, lahan, kota tetapi juga semua unsur, bisnis, masyarakat, dan sebagainya yang berprinsip memenuhi kebutuhan sekarang tanpa mengorbankan pemenuhan kebutuhan generasi masa depan. Menurut Effendi dalam Abdurrahman (2003: 7-8), pembangunan berkelanjutan adalah suatu proses pembangunan yang pemanfaatan sumber dayanya, arah invensinya, orientasi pengembangan teknologinya dan perubahan kelembagaannya dilakukan 
secara harmonis dan dengan amat memperhatikan potensi pada saat ini dan di masa depan dalam pemenuhan kebutuhan dan aspirasi masyarakat.

\section{Penguatan Kelembagaan dalam Pembangunan}

Penguatan kelembagaan Pemerintah Daerah menurut Eaton (1986), dapat diartikan sebagai upaya membangun organisasi, sistem-sistem, kemitraan, orang-orang dan prosesproses secara benar untuk menjalankan agenda atau rencana tertentu. Penguatan kapasitas kelembagaan Pemerintah Daerah oleh karenanya berkaitan dengan perkembangan kapasitas individu (individual capability development), pembinaan kapasitas organisasi (organizational capacity building), dan pembinaan kapasitas kelembagaan (institusional capacity building). Pengertian penguatan kelembagaan tersebut memberikan gambaran bahwasannya terdapat banyak hal harus diperhatikan dan dicermati secara jeli agar penguatan kapasitas dapat membuahkan hasil nyata, bermanfaat, dan menimbulkan dampak positif. Lebih lanjut Eaton (1986) mengatakan Penguatan kelembagaan pemerintah daerah diarahkan bertujuan untuk mengembangkan keterampilan dan kompetensi individual sehingga masing-masing individu mampu melaksanakan tugas dan tanggung jawab yang diembannya, mengembangkan para pegawai, budaya, sistem dan proses-proses ke dalam otoritas/kewenangan unit-unit organisasi dalam rangka mencapai tujuan unit-unit organisasi masing-masing, dan mengembangkan serta menguatkan jalinan keluar (development and strengthening of external links) dalam rangka menumbuh kembangkan kemitraan secara intensif, ekstensif, dan solid.

\section{Partisipasi Masyarakat dalam Pembangunan}

Andrea dan Gaventa dalam Karianga (2011), menjelaskan bahwa partisipasi adalah proses tumbuhnya kesadaran terhadap hubungan di antara stakeholder yang berbeda dalam masyarakat, yaitu antara kelompok-kelompok sosial dan komunitas dengan pengambil kebijakan dan lembaga-lembaga jasa lain. Bank dunia memberi batasan partisipasi masyarakat sebagai Pertama, keterlibatan masyarakat yang terkena dampak pengambilan keputusan tentang hal-hal yang harus dikerjakan dan cara mengerjakannya. Kedua, keterlibatan tersebut berupa kontribusi dari masyarakat dalam pelaksanaan kegiatan yang telah diputuskan. Ketiga, bersama-sama memanfaatkan hasil program sehingga masyarakat mendapatkan keuntungan dari program tersebut.

\section{Konsep dan Definisi Sinergitas}

Menurut Najiyati dan Rahmat (2011), Sinergitas dapat terbangun melalui dua cara yaitu: (1) Komunikasi; (2) Koordinasi.

\section{Taman Nasional}

Peraturan Pemerintah Nomor 108 Tahun 2015 menjelaskan bahwa, Taman Nasional adalah kawasan pelestarian alam yang mempunyai ekosistem asli, dikelola dengan sistem zonasi yang dimanfaatkan untuk tujuan penelitian, ilmu pengetahuan, pendidikan, menunjang budidaya, pariwisata, dan rekreasi. Pembentukan Taman Nasional di Indonesia sedikit banyak meniru konsep pembentukan Taman Nasional di Amerika Serikat, dalam konteks proses pembentukannya. Sebagaimana terjadi di sana, pembentukan Taman Nasional diawali dengan adanya pengalokasian kawasan tertentu atau kawasan yang sengaja disisihkan sebagai kawasan tutupan. Pada era tahun 80-an yang merupakan awal pembentukan Taman Nasional di Indonesia, penetapan Taman Nasional dilakukan melalui perubahan status pengelolaan terhadap kawasan-kawasan yang sebelumnya telah ditetapkan Pemerintah Hindia Belanda sebagai suaka alam, suaka margasatwa, monumen alam, dan cagar alam. 


\section{METODE PENELITIAN \\ Jenis Penelitian}

Menurut Moleong (2014) mengemukakan Fungsi dan Pemanfaatan Penelitian Kualitatif dimanfaatkan untuk keperluan meneliti latar belakang fenomenal yang tidak dapat diteliti melalui penelitian kuantitatif dan digunakan oleh peneliti bermaksud meneliti sesuatu secara mendalam. Metode penelitian kualitatif sangat sesuai digunakan untuk mengkaji masalah penelitian mengingat bahwa judul yang peneliti angkat bersifat mengkaji penguatan kelembagaan lokal melalui pengkajian terhadap sinergitas pihak dengan masyarakat dalam mengelola Taman Nasional Sebangau.

\section{Lokasi Penelitian}

Lokasi penelitian ini dilakukan di Balai Taman Nasional Kawasan Sebangau. Hal ini dilakukan karena Balai Taman Nasional Kawasan Sebangau dinilai sebagai salah satu pemerintah lokal yang berperan aktif dalam mengelola Taman Nasional Sebangau serta Kelurahan Habaring Hurung yang berbatasan langsung dengan Taman Nasional Sebangau.

\section{PEMBAHASAN}

\section{Penguatan Kelembagaan Lokal Melalui Balai Taman Nasional dalam Mengelola Taman Nasional Kawasan Sebangau \\ Pengembangan Sumber Daya Manusia di Balai Taman Nasional Sebangau}

Dalam penelitan ini yang pertama yang ingin dibahas peneliti adalah pengembangan sumber daya manusia di Balai Taman Nasional Sebangau. Adapun permasalahan yang ingin dipecahkan dalam penelitian ini adalah yakni sebagai berikut:

1) Sistem Rekrutmen

Menurut Badan Kepegawaian Negara (2009) dalam disertasi Hariono mendefinisikan rekrutmen sebagai suatu proses yang dilakukan organisasi untuk mencari dan menemukan pegawai yang dibutuhkan, merupakan aktivitas manajemen sumber daya manusia. Hasil yang didapatkan dari proses rekrutmen adalah sejumlah tenaga kerja yang akan memasuki proses seleksi, yaitu proses untuk menemukan kandidat yang mana yang paling layak untuk mengisi jabatan tertentu yang tersedia di kelembagaan. Adapun dasar proses penerimaan pegawai Balai Taman Nasional Sebangau Kepala Balai Taman Nasional Sebangau hanya melakukan evaluasi-evaluasi terkait pegawai yang ingin bekerja di Balai Taman Nasional Sebangau yang nantinya akan direkomendasikan ke Balai Diklat atau Kementerian. Terkait pegawai yang ingin di rekrut Balai Diklat lah yang menentukan maupun menyediakan pegawai-pegawai baru yang akan berkerja di Balai Taman Nasional Sebangau. Dengan demikian sistem rekrutmen bukan kekuasaan Kepala Balai Taman Nasional Sebangau melainkan Balai Diklat yang menetapkan pegawai-pegawai Balai Taman Nasional Sebangau.

2) Pelatihan

Pelatihan dan pengembangan merupakan dua konsep yang sama, yaitu untuk meningkatkan pengetahuan, keterampilan, dan kemampuan (Hariandja dalam Haryono, 2002). Tetapi dilihat dari tujuannya, utamanya kedua konsep tersebut dapat dibedakan. Pelatihan lebih ditekankan kepada peningkatkan kemampuan untuk melakukan pekerjaan yang spesifik pada saat ini, sedangkan pengembangan untuk melakukan pekerjaan pada masa yang akan datang, yang dilakukan melalui pendekatan yang terintegrasi dengan kegiatan lain untuk mengubah perilaku kerja. 
Balai Taman Nasional Sebangau hanya merekomendasikan pegawainya ke kantor pusat untuk pelatihan dasar pegawai pemula seperti bagaimana cara-cara memahami cara memadamkan api ataupun harus mengetahui segitiga api. Dalam kegiatan nantinya disini pegawai mengusulkan apa yang ingin direncanakan untuk kedepannya. Maka dari itu Pelatihan bukan Balai Taman Nasional Sebangau yang melaksanakan untuk pegawai-pegawainya melainkan yang menyelenggarakan Balai Diklat ataupun Kementerian.

3) Kondisi Kerja

Kondisi kerja yaitu serangkaian keadaan lingkungan kerja yang menjadi tempat bekerja daripada karyawan yang bekerja dilingkungan tersebut. Disini yang dimaksud kondisi kerja yang baik yaitu nyaman dalam menjalankan aktivitasnya dengan baik, meliputi segala sesuatu yang ada dilingkungan karyawan yang dapat mempengaruhi kinerja keselamatan dan keamanan kerja. Adapun kondisi kerja Balai Taman Nasional Sebangau dari segi kualitas sangat bagus karna sudah tersedia ukuran-ukuran faktor penilaiannya yang disediakan oleh Balai Diklat menjadikan pegawai lebih mudah menjalankan kerjanya seperti mengumpulkan angka kredit.

4) Ketersediaan Tenaga Teknis dan Profesional

Pada kenyataannya Balai Taman Nasional Sebangau sangat kekurangan ketersedian tenaga teknis dan profesional terkait kurangnya pegawai yang bekerja di Balai Taman Nasional Sebangau. Hal ini jelas mengakibatkan kurang maksimalnya pelayanan pegawai Balai Taman Nasional Sebangau dengan masyarakat-masyarakat maupun lembaga lain. Seperti kenyataannya luas Taman Nasional Sebangau 500 ribu Ha yang ada di Kalimantan Tengah namun yang mengelola Taman Nasional hanya 50 orang pegawai Balai Taman Nasional Sebangau. Hal tersebut mengakibatkan pegawai-pegawai Balai Taman Nasional Sebangau sering bekerja diluar tugas pokok dan fungsinya untuk membantu pelayanan dengan masyarakat-masyarakat yang berada di kawasan Taman Nasional Sebangau.

5) Pengembangan Pelatihan Sumber Daya Manusia (Terkait Evaluasi Pegawai dan Pengkajian)

Adapun pelatihan pendidikan pada dasanya hanya dilaksanakan di Balai Diklat atau Kementerian yang tahapannya bukan dari argumen Balai Taman Nasional Sebangau melainkan Balai Taman Nasional Sebangau hanya mengusulkan mana yang akan dievaluasi dan jenis pelatihan yang diinginkan. Pelatihan yang dilaksanakan Balai Diklat merupakan salah satu upaya peningkatan pengetahuan, sikap dan keterampilan pegawai dalam rangka meningkatkan mutu dan kinerja pegawai. Kepala Balai Taman Nasional Sebangau berhak mengevaluasi kinerja pegawai terkait kehadiran yang dimana nantinya akan dikenakan sanksi apabila jarang turun atau pun malas disaat bekerja. Kepala Balai Taman Nasional Sebangau juga dapat menaikkan jabatan pegawainya bagi yang dinilai kinerja bagus yang nantinya akan direkomendasikan ke Balai Diklat.

\section{Penguatan Organisasi}

Mengenai bagaimana upaya yang dilakukan dalam rangka penguatan organisasi terletak pada persoalan pemanfaatan personil, bagaimana mendesain struktur manajerial dan persoalan pengembangan jaringan atau network.

1) Sistem Insentif

Insentif merupakan tambahan penghasilan yang berupa uang, barang dan sebagainya yang diberikan untuk mendorong gairah kerja para karyawan agar 
lebih meningkatkan produktivitas kerja dalam rangka mencapai tujuan yang telah ditetapkan oleh suatu instansi. Instansi yang dimaksud disini yaitu Balai Taman Nasional Sebangau.

Insentif yang diberikan Balai Taman Nasional Sebangau kepada pegawai sudah diatur oleh menteri keuangan dimana insentif untuk seluruh pegawai Taman Nasional Sebangau memotivasi untuk hadir kerja yang diberikan Kementrian atau Balai Diklat. Pegawai yang dinilai bagus nantinya diberikan kesempatan untuk melanjutkan pendidikannya guna menaikkan gradenya yang anggarannya di tanggung Balai Diklat. Kalau insentif dari Kepala Balai Taman Sebangau langsung tidak ada diberikan kepada pegawai Balai Taman Nasional Sebangau.

Seperti halnya Kepala Resort Kelurahan Habaring Hurung menyatakan bahwa insentif yang diberikan Kepala Balai Taman Nasional Sebangau tidak ada diberikan dan adapun kegiatan yang dilaksanakan Kepala Resort Kelurahan Habaring Hurung seperti mengajar anak-anak Kelurahan Habaring Hurung menggunakan duit pribadinya sendiri. Hal tersebut dilaksanakan Kepala Resort Habaring Hurung karena rasa pedulinya terhadap pentingnya pendidikan bagi anak-anak kedepannya dan mengajarkan pentingnya sumber daya alam bagi kehidupan bermasyarakat walaupun dana yang diberikan Kepala Balai Taman Nasional Sebangau tidak ada demi menunjang keberlangsungan kegiatan yang ada di Kelurahan Habaring Hurung.

2) Pemanfaatan personil

Salah satu unsur dalam penguatan organisasi adalah pendayagunaan aparatur atau biasa disebut pemanfaatan personil, yaitu menempatkan pegawai sesuai dengan kompetensinya, atau istilah lainnya adalah The right man on the right place. Dengan menerapkan prinsip ini maka akan menciptakan pegawai yang memiliki kompetensi yang tepat atau menciptakan aparatur yang profesional dalam bidangnya. Dalam menjalankan tugas Balai Taman Nasional Sebangau proses perencanaannya sudah tertata yang dimana mekanisme standar operasional prossedur (SOP) sudah diatur oleh Undang-Undang yang udah ditetapkan. Dengan adanya standar operasional prosedur pegawai Balai Taman Nasional Sebangau mengacu kepada Undang-Undang dengan menjalankan tugas-tugas pokok dan fungsinya.

Akan tetapi dengan kurangnya ketersediaan sumber daya manusia mengakibatkan Kepala Resort Kelurahan Habaring Hurung harus bekerja diluar tugas pokok dan fungsinya dalam menjalankan kegiatan yang dilaksanakan di Kelurahan Masyarakat Habaring Hurung dengan mengajarkan anak-anak les bahasa inggris serta komputer tiap hari sabtu dan minggu. Meskipun demikian, Kepala Resort Kelurahan Habaring Hurung menyatakan tetap menjalankan tugasnya dengan baik dimana kegiatan yang dilaksanakan sangat menarik perhatian masyarakat setempat dengan terbantunya anak-anak Kelurahan Habaring Hurung dalam meningkatkan kemampuan pendidikannya. Dengan demikian masyarakat sangat mendukung adanya kegiatan yang dilaksanakan di Resort Kelurahan Habaring Hurung.

3) Komunikasi dan Struktur Manajerial

Adapun proses komunikasi yang dilaksanakan Balai Taman Nasional Sebangau dengan masyarakat-masyarakat yang tinggal di kawasan Taman Nasional Sebangau adalah dengan cara nonformal. Balai Taman Nasional Sebangau menjalankan komunikasinya dengan masyarakat dengan cara bersosialisasi ataupun mengajak patroli masyarakat yang terpilih masuk ke dalam hutan untuk 
mengenal bahwa pentingnya hutan sebagai sumber air atau penyangga kehidupan manusia.

Selain itu Balai juga berpartisipasi memberikan berupa bantuan terhadap masyarakat seperti pelatihan penangkaran, bantuan desa penyangga baik sistem pelatihan, barang dan membudidayakan jamur. Dengan cara yang dilaksanakan Balai Taman Nasional Sebangau, masyarakat akan mengetahui bahwa Balai Taman Nasional Sebangau adalah pihak yang mengelola atau mutlak pengelola Taman Nasional Sebangau.

\section{Kepemimpinan}

Kepemimpinan memegang peranan penting dalam menentukan kesuksesan program pembangunan kapasitas suatu organisasi. Kepemimpinan yang dipersyaratkan dalam pembangunan kapasitas antara lain yaitu keterbukaan (apenness), penerimaan terhadap ideide baru (receptivity to new ideas), kejujuran (honesty), perhatian (caring), penghormatan terhadap harkat dan martabat (dignity) serta penghormatan kepada orang lain (respect to people). Semakin besar pemimpin memberikan kepercayaan dan suasana kondusif pada staf untuk berkembang, maka akan semakin sukseslah program pembangunan kapasitas dalam sebuah organisasi.

Secara umum masyarakat setuju adanya Taman Nasional Sebangau dan Balai Taman Nasional Sebangau selaku pihak yang mengelola Taman Nasional Sebangau. Kepala Balai Taman Nasional Sebangau mendekatkan diri dengan masyarakat dengan cara bersosialisasi kepada masyarakat menjelaskan betapa pentingnya air yang harus dijaga untuk menyangga kehidupan manusia, ikan untuk kehidupan sehari-hari masyarakat serta pengawasan ekosistem agar terhindar dari kebakaran yang akan terjadi. Dengan keberadaan Taman Nasional Sebangau, hal tersebut menjadikan masyarakat dapat merasakan langsung fungsi dan manfaatnya bahwa Taman Nasional layak dijaga demi kelangsungan hidup masyarakat.

\section{Reformasi Kelembagaan}

Reformasi kelembagaan pada intinya yaitu menunjuk kepada pengembangan iklim dan budaya yang kondusif bagi penyelenggaraan program kapasitas personal dan kelembagaan menuju realisasi tujuan yang diinginkan. Reformasi institusi berarti mengubah organisasi dan/atau individu dalam membuat keputusan dan melakukan aktivitas-aktivitas. Sehingga, membangun kapasitas melalui reformasi institusi akan mengakibatkan pengembangan sistem dalam organisasi.

Pembuatan keputusan dan pelaksanaan kegiatan-kegiatan yang dilakukan oleh Balai Taman Nasional Sebangau merujuk kepada visi dan misi yang telah ditetapkan oleh Presiden Indonesia. Visi dari Balai Taman Nasional Sebangau adalah terwujudnya Indonesia yang berdaulat, mandiri dan berkepribadian berlandaskan gotong royong. Berdasarkan visi, misi dan tujuan pembangunan nasional peran utama kementerian lingkungan hidup dan kehutanan adalah:

1. Menjaga kualitas Lahan Hutan yang memberikan daya dukung, pengendalian pencemaran, pengelolaan Daerah Aliran Sungai (DAS), keanekaragaman hayati serta pengendalian perubahan iklim;

2. Menjaga luasan dan fungsi hutan untuk menopang kehidupan, menyediakan hutan untuk kegiatan sosial, ekonomi rakyat, dan menjaga jumlah dan jenis flora \& fauna;

3. Memelihara kualitas lingkungan hidup, menjaga hutan, dan merawat keseimbangan ekosistem dan keberadaan sumberdaya;

Dalam mendukung kebijakan Balai Taman Nasional, Kepala Balai Taman Nasional Sebangau mensinkronkan kebijakan Pemerintah daerah dengan mempertimbangkan UndangUndang yang berlaku. Terkait relevansi visi misi Balai Taman Nasional Sebangau bahwa 
untuk puluhan tahun kedepan masih relevan tidak akan berubah-ubah dalam melaksanakan kegiatan 3 konservasi yang dimana indikator tercapainya visi misi Balai Taman Nasional Sebangau adalah menurunkan kebakaran hutan dan meningkatkan populasi satwa liar yang ada di Taman Nasional Sebangau.

Beberapa upaya yang dilakukan oleh Balai Taman Nasional Sebangau untuk mewujudkan pengelolaan Taman Nasional Sebangau dengan cara bersosialisasi dan komunikasi dengan masyarakat. Dalam menyusun program kerja yang akan dilaksanakan, Balai Taman Nasional Sebangau mengacu kepada Standar Operasional Prosedur yang telah disediakan oleh Balai Diklat.

Namun permasalahan yang patut diperhatikan adalah Dana Anggaran. Dalam mewujudkan pengelolaan Taman Nasional dan melakukan pembangunan kapasitas Balai Taman Nasional Sebangau selaku aktor yang menyelenggarakan Taman Nasional tersebut harus didukung oleh kekuatan anggaran yang mana dana anggaran Balai Taman Nasional Sebangau yang menyediakan adalah Balai Diklat atau Kementerian.

Seperti yang terjadi di Kelurahan Habaring Hurung diperlukannya dukungan dana guna mendukung program-program yang telah direncanakan oleh Balai Taman Nasional Sebangau agar semua kegiatan berjalan dengan lancar. Kegiatan yang dilaksanakan di Resort Kelurahan Habaring Hurung mengalami kendala terkait anggaran ataupun tenaga teknis sehingga Kepala Resort Habaring Hurung tetap menjalankan tugasnya tetapi dengan dana pribadi.

Hal ini yang harus menjadi perhatian khusus bagi Kepala Balai Taman Nasional Sebangau untuk bisa berkomunikasi langsung dengan Balai Diklat terkait masalah dana anggaran untuk menjalankan program yang telah direncanakan oleh Balai Taman Nasional Sebangau.

\section{Sinergitas Balai Taman Nasional dengan Masyarakat Kelurahan Habaring Hurung dalam Mengelola Taman Nasional Kawasan Sebangau}

Dalam penelitian ini, peneliti tidak hanya mengkaji tentang penguatan kelembagaan, namun disini peneliti juga mengkaji Sinergitas Balai Taman Nasional dengan Masyarakat Kelurahan Habaring Hurung. Sinergitas tersebut dapat dilihat melalui komunikasi dan koordinasi yang dilakukan antara Balai Taman Nasional Sebangau selaku pengelola Taman Nasional Sebangau dan Masyarakat Kelurahan Habaring Hurung selaku pihak atau masyarakat yang tinggal dikawasan Taman Nasionl Sebangau.

\section{Komunikasi}

Komunikasi disini yang dimaksud adalah suatu pembentukan, penyampaian, penerimaan dan pengolahan pesan yang terjadi di dalam diri seseorang dan atau diantara dua atau lebih dengan tujuan tertentu. Hal pertama yang dikaji dalam konsep sinergitas ini adalah terkait komunikasi antara Balai Taman Nasional Sebangau dengan Masyarakat Kelurahan Habaring Hurung. Dalam proses pengelolaan Taman Nasional Sebangau sangat dibutuhkan komunikasi dengan masyarakat. Hal ini tidak lain karena masyarakat adalah pihak yang paling dekat dan bersentuhan langsung dengan Taman Nasional Sebangau.

Adapun komunikasi Balai Taman Nasional Sebangau dengan Masyarakat Kelurahan Habaring Hurung dalam proses pengelolaan Taman Nasional Sebangau khususnya Kelurahan Habaring Hurung tidak terlaksana dengan baik. Jarangnya Balai Taman Nasional Sebangau melakukan kunjungan-kunjungan ataupun bersosialisasi terhadap masyarakat Kelurahan Habaring Hurung sehingga mengakibatkan adanya masyarakat yang tidak mengetahui dengan keberadaan Taman Nasional disekitar kawasan masyarakat serta masyarakat sebagian tidak mengetahui dan sebagian mengetahui Balai Taman Nasional Sebangau selaku pengelola Taman Nasional Sebangau. 
Dengan demikian walaupun masyarakat Kelurahan Habaring Hurung pihak yang paling dekat dan bersentuhan langsung dengan kawasan Taman Nasional Sebangau sebagian masyarakat Kelurahan Habaring Hurung tidak mengetahui apa itu Taman Nasional dan terkait apa-apa saja yang dilarang serta sanksi apa yang diterima apabila masyarakat melanggar sanksi yang telah diberlakukan Balai Taman Nasional Sebangau. Kurangnya komunikasi yang dilakukan Balai Taman Nasional membuat setiap program yang telah direncanakan untuk mewujudkan visi misinya tidak sesuai rencana. Hal ini mengakibatkan sebagian masyarakat tidak peduli dengan adanya keberadaan Taman Nasional Sebangau.

\section{Koordinasi}

Terkait koordinasi sering dikaitkan dengan perihal mengatur suatu organisasi atau kegiatan sehingga peraturan dan tidakan yang akan dilaksanakan tidak saling bertentangan atau simpang-siur. Dalam penelitian ini konsep sinergitas peneliti tidak hanya mengkaji komunikasi Kelurahan Habaring Hurung dengan Balai Taman Nasional Sebangau tetapi juga dibutuhkan koordinasi sebagai kewenangan untuk menggerakkan, menyelaraskan, menyerasikan dan menyeimbangkan kegiatan-kegiatan yang spesifik atau berbeda, agar nantinya semua terarah pada pencapain tujuan tertentu pada waktu yang telah ditetapkan. Sehingga setiap program yang dilakukan oleh Balai Taman Nasional untuk mewujudkan visi dan misi dibutuhkan partisipasi langsung dari masyarakat.

Adapun koordinasi yang dilakukan Balai Taman Nasional Sebangau di Kelurahan Habaring Hurung yaitu melaksanakan program kegiatan seperti mengajar anak-anak les tambahan diantaranya bahasa inggris dan komputer. Anak-anak diajari cara menanam tumbuh-tumbuhan dan merawatnya dengan baik serta menjaga lingkungan hidup. Adapun keberadaan Resort membuat masyarakat mendukung sepenuhnya program yang telah dijalankan Balai Taman Nasional Sebangau.

Namun pada umumnya kegiatan Balai Taman Nasional Sebangau semakin berkurang dimana yang dulunya Balai Taman Nasional Sebangau tidak hanya memberikan les tambahan bagi anak-anak akan tetapi sering memberikan bantuan seperti melakukan pelatihanpelatihan, penangkaran ikan dan sapi. Masyarakat juga sering dibawa patroli oleh polisi hutan untuk memonitoring keberadaan Taman Nasional yang ada di Kelurahan Taman Nasional Sebangau. Masyarakat juga mengambil peran dalam membantu pengelolaan Balai Taman Nasional Sebangau.

Adapun yang menjadi faktor permasalahan yang dihadapi Balai Taman Nasional Sebangau dengan masyarakat Kelurahan Habaring Hurung yaitu terkait tata batas lahan usaha 2 yang berada di kawasan Taman Nasional Sebangau milik masyarakat yang diklaim Balai Taman Nasional Sebangau berada dikawasan Taman Nasional Sebangau. Sehingga permasalahan ini berbuntut panjang antara Balai Nasional Sebangau dengan masyarakat Kelurahan Habaring Hurung terutama dengan Lurah Habaring Hurung. Lurah Habaring Hurung atau beberapa masyarakat menolak menyatakan bahwa lahan usaha 2 milik Taman Nasional. Hal ini dikarenakan masyarakat mempunyai sertifikat asli dari Negara bahwa lahan usaha 2 jelas milik masyarakat.

Alasan sebagian masyarakat menolak termasuk Lurah Habaring Hurung jelas karena mereka tidak mau sumber penghasilan mereka dijadikan kawasan Taman Nasional Sebangau. Hal ini dikarenakan karena lahan usaha 2 apabila dijadikan kawasan Taman Nasional Sebangau otomatis mengakibatkan masyarakat tidak lagi bisa bekerja di kawasan tersebut.

\section{DAFTAR PUSTAKA}

Abdurrahman, H. (2003). Pembangunan Berkelanjutan Dalam Pengelolaan Sumber Daya Alam Indonesia. Seminar Pembangunan Hukum Nasional VIII (hal. 1-31). 
Denpasar: Badan Pembinaan Hukum Nasional Departemen Kehakiman Dan Hak Asasi Manusia RI.

Agusta, I. (2007). Penguatan Kelembagaan Untuk Pengembangan Kawasan Agropolitan. Pelatihan Nasional Dan Implementasi Pengembangan Kawasan Agropolitan (hal. 132). Bogor: P4W-LPPM-IPB Dan Yayasan Tunas Mandiri Nasional.

Akhmaddhian, S. (2013). Peran Pemerintah Daerah Dalam Mewujudkan Hutan Konservasi Berdasarkan Undang-Undang Nomor 41 Tahun 1999 Tentang Kehutanan. Kabupaten Kuningan: Fakultas Hukum Universitas Kuningan.

Damayanti, A. (2010). Kebijakan Pembangunan Wilayah Berbasis Pengelolaan Das Terpadu Dan Berkelanjutan. Bogor: Institut Pertanian Bogor.

Eaton, J. W. (1986). Pembangunan Lembaga Dan Pembangunan Sosial. Jakarta: UI Press.

Faozan, H. (2005). Penguatan Kapasitas Kelembagaan Pemerintah Daerah Sebagai Agenda Utama Optimasi Pengelolaan Daerah Perbatasan. Jakarta: Lembaga Administrasi Negara.

Hartono. (2008). Taman Nasional Mandiri. Reuni Akbar Dan Seminar Lustrum IX 2008 (hal. 1-24). Yogyakarta: Fakultas Kehutanan UGM.

Haryono, B. S. (2011). Pembangunan Kapasitas Pemerintahan Daerah Dalam Menyelenggarakan Urusan Kesehatan di Kota Malang. Malang: Fakultas Ilmu Administrasi Universitas Brawijaya.

Idrus, M. (2009). Metode Penelitian Ilmu Sosial. Yogyakarta: PT. Gelora Aksara Pratama.

Indradi, S. S. (2008). Administrasi Pemerintahan Lokal. Malang: Agritek Pembangunan Nasional.

Karianga, H. (2011). Partisipasi Masyarakat Dalam Pengelolaan Keuangan Daerah. Bandung: PT. Alumni.

Keputusan Menteri Kehutanan Republik Indonesia Nomor 6186/Kpts-II/2002.

Kirsfianti Ginoga, M. L. (2005). Kajian Kebijakan Pengelolaan Hutan Lindung. Sulawesi Selatan: Penelitian Sosial Dan Ekonomi.

Moleong, L. J. (2014). Metodologi Penelitian Kualitatif. Bandung: PT. Remaja Rosdakarya.

Novita Sari, I. N. (2013). Pengembangan Kapasitas Kelembagaan Pemerintah Daerah Dalam Meningkatkan Kualitas Pelayanan Perizinan Terpadu. Malang: Kantor Pelayanan dan Perizinan Terpadu Kabupaten Kediri.

Peraturan Pemerintah No. 108 Tahun 2015 Tentang Perubahan Atas Peraturan Pemerintah No. 28 Tahun 2011 Tentang Pengelolaan Kawasan Suaka Alam Dan Kawasan Pelestarian Alam. 
Peraturan Pemerintah No. 44/2004 Tentang Perencanaan Kehutanan.

Qodir, A. (2011). Analisis Kelembagaan Dalam Upaya Pembangunan Kesejahteraan Masyarakat. Depok: Fakultas Ilmu Sosial Dan Ilmu Politik Depok.

Rahmawaty. (2004). Hutan: Fungsi Dan Peranannya Bagi Masyarakat. Sumatera Utara: Fakultas Pertanian Program Ilmu Kehutanan Universitas Sumatera Utara.

Rencana Straregis Taman Nasional Sebangau Tahun 2015-2019

Soetomo. (2010). Strategi-strategi Pembangunan Masyarakat. Yogyakarta: Pustaka Pelajar.

Sugiyono. (2011). Metode Penelitian Administrasi. Bandung: Alfabeta.

TAMAN NASIONAL SEBANGAU. (2015, Agustus 2). Taman Nasional Sebangau. Dipetik Oktober 18, 2016, dari Taman Nasional Sebangau: https://www.tnsebangau.com/taman-nasional-sebangau/

Thaha, R. (2008). Penataan Kelembagaan Pemerintah Daerah. Jakarta.

Triana Rahmawati, I. N. (2013). Sinergitas Stakeholders Dalam Inovasi Daerah. Malang: Jurusan Administrasi Publik, Fakultas Ilmu Administrasi.

Undang-Undang Dasar 1945 Pasal 18.

Undang-Undang Nomor 32 Tahun 2004 tentang Pemerintah Daerah.

Undang-Undang Nomor 5 Tahun 1990 Tentang Konservasi Sumber Daya Alam Hayati dan Ekosistem.

Yaniawati, R. I. (2014). Metodologi Penelitian Kuantitatif, Kualitatif, dan Campuran Untuk Manajemen, Pembangunan dan Pendidikan. Bandung: PT. Refika Aditama. 